\title{
Perspectives for a Social Integration of Human rights in the Muslim world
}

\section{Efrem Garlando}

Efrem Garlando, 23, is an undergraduate student in Political Science at the LUISS University, Rome. He is writing his thesis on the concept of peace in the Middle East considering the three main monotheistic religions in that area. Currently he is director of Luiss: Discovering International Organization - UNHCR in partnership with UNHCR and Luiss CROIE Centre of Research. His interests include security studies, political economy, conflict resolution and democratic transition.

\begin{abstract}
Human Rights are defined ${ }^{2}$ as sort of humankind "Esperanto", a neutral language able to promote the difficult task of dialogue across communities. When speaking about "Islam", it is easy or generates a misunderstanding, because the word Islam does not refers to a monolithic entity: Ummah, the global community of all Muslim believers, is indeed plural and fragmentary from both a geographical and a cultural perspective. In the course of my essay, I will start from the work of John Rawls and Abdullahi Ahmed An- Naim, then focus on a new concept of Human Rights, stressing practical tools rather than hermeneutical ones. As a matter of fact this project should start within the Islamic world in order to be more easily accepted. Furthermore, it is necessary to firstly undertake this task there, so that it cannot be claimed to be the result of western cultural imperialism. The Islamic countries ought to rethink the idea of "public reason", which must not be confused with the "reason of the sovereign" and should instead outcomes from the dialogue between people. This is possible thanks to a progressive rooting out of the traditional concept of Sharia and a renovated concept of ijtibad, the concept of personal reasoning, so that the Islamic world can achieve a stronger critical sense towards itself and its religious dogmatism.
\end{abstract}

Keywords: Islam, Public reason, Ummah, Ijtihad, Human Rights

\footnotetext{
2 Anselmo D. (2007) Shari'a e Diritti Umani (Introduction)
} 


\section{Introduction}

We have recently been facing a new wave of globalization characterized by a greater interdependence that is directly reflected on the individual, one that has modified by time the outdated economic and social superstructure built after the World War II. These bottom-up transformations require legitimisation and all the levels of governance must become aware of this evolution. Not less importantly, this evolution requires a rethinking of the impression of religion in present-days in relation to our multicultural society. The rise of such a powerful crisis on the social and political level all over the world have deeply touched the Islamic humankind, bringing into question the secular perspective related to the religious identity. The practicable and interpretative methodologies contribute to create solutions on the field, highlighting meaningmaking practices in order to observe reasonable outcomes. This article describes a basic solution for the integration between different ideas of a Human Being's public life. Starting from the contemporary situation in the Middle East and its religious background, I contextualize the current identification of Human Rights in the Islamic public affairs comparing it with the western culture in order to find an unambiguous context for Human Rights and therefore determine a cornerstone of a further essential approach able to create a common field for these themes: the Islamic liberalism.

\section{Is this a cultural crisis?}

Islam is not merely a religion: it is considered a holistic and all-embracing concept, which includes different aspects and a wide range of principles. The preliminary and necessary consideration for studying Islam is that there is no a single Islam but, on the contrary, different ones. Ummah is an Arabic word, meaning nation or community. It is a synonym for ummat alIslamiyah, the Islamic Nation, and it is commonly used to mean the collective community of the Islamic people. In the Quran, the Ummah typically refers to a single group that shares common religious beliefs, specifically those that are the objects of a divine plan of salvation. In the context of Pan-Islamism and politics, the word Ummah can be used to mean the Commonwealth of the Believers. $^{3}$. This community is spread in all five continents reaching 1.2 billion of believers (according to Pew Research Centre, 23.2\% of the world population).

As the work of Mr. Talbi shows, we cannot include the Islamic culture in a narrow scheme ${ }^{4}$. The Dar Al-Islam, literally "the home of Islam", should be extended to include a wider framework. In

\footnotetext{
3 The same Muslim, during childhood, learnt to be part of this community and being firstly believers and then part of a national community. Cf. M. Charfi (1998), Islam y libertad: el malantendido Historìco (p. 121)

${ }^{4}$ Ibid. (p. 124).
} 
fact Islam lacks hierarchical structures and central authority and except for a core of shared inalienable principles, Islam is distinguished by an extreme flexibility and an unsuspected dynamism, where Islamic official "schools" have the legitimacy to supply autonomous interpretation of the Quran. I emphasize this concept because it is supposed that the normal connotation of the Islamic world as a static and stiff religion sorted recently by media information must be refused. Therefore in the Islamic world we can find different cultures, which come from different traditions, national governments and so forth. According to Talbi, cultures are composed of two components: the first one is firm and homogeneous (synchronic aspects); the second one is in continuous variation and development diachronic aspect ${ }^{5}$. We should arrange a double approach able to consider both aspects in order to prevent a partial or falsified vision that may lead either to eradication from tradition nor to a refusal of change.

Nowadays the multicultural society is by the time part of our daily life. In fact cultures cannot be exempt from considering other cultures. However, is it possible to reach a complete recognition between cultures, even if they have fundamental values which are in contrast? For intellectual uprightness the solution to this requisite is controversial. Different scholars consider this possibility. Kymlicka ${ }^{6}$ recognizes a possibility for integration only if cultures deserve this recognition, bringing evidence which is justifiable by each member of the society. Habermas sustains the political acknowledgement only if that group of people is able to perpetuate so autonomously inside society. This process can reach a practical solution if cultures are living in reasonable disagreement ${ }^{7}$.

This short foreword is important to address my work: in fact these considerations consist in a platform for a wide support of Human Rights in general and above all in the Islamic Countries. Human Rights are the most suitable support for creating a constructive dialogue between cultures. The traditional matter to face at the moment is if it is possible to have a universal recognition. This theme usually clashes against religious visions of some populations on our planet, in which there is no complete secularized society and where religion continues to play a key role in the public and private lives of the citizens.

We know that the reference point about this matter is the Universal Declaration of Human Rights (1948). Muslim States reactions brought to different responses: a straight opposition to this declaration seen as a western imposition, or an Islamic reformulation without dispositions

\footnotetext{
5 Talbi (1981); Le vie del Dialogo nell'Islam (p. 143)

${ }^{6}$ Kymlica (2001); Politics in the Vernacular: Nationalism, Multiculturalism, Citizenship (p. 34)

${ }^{7}$ Habermas (1996); The inclusion of the other (p. 55)
} 
contrary to Shari' $a$. Several documents were published, both by public and private organisations ${ }^{8}$. It is important to give evidence to some positive and comforting signals analyzing the Arabic Charter on Human Rights: in fact in this document the shortage of a specific lure of Shari' $a$ is deemed together with the insertion of particular western rights and the creation of specific legal guarantees for protecting them.

The individualistic anthropology on Human Rights used to legitimate the Rights of freedom is overcome by time and it remains obsolete regarding social and cultural rights. Universalism of Human Rights should be recognized as an ethic and juridical code generally accepted as defined by Francisco de Victoria and Grozio: Ius as qualitas moralis. The second assertion for defining the universality of Human Rights comes straight from the subject of these privileges: humanity. This natural law approach would consider all people as legitimate holders of these principles but this point of view often remains obsolete and without basis. This is why it may be right to consider universalism as double: regarding both contents and holders.

The union of the standards could solve once and for all this problem but, even if it were possible to reach an agreement about contents, who will have the possibility to claim these rights? For instance, a threefold inequality exists in the Islam cultures: man vs. woman, believers vs. nonbelievers and master vs. slave.

\section{Which context for Human Rights?}

I am looking for a proposal, which goes beyond the previous methods. Nowadays we are standing in a sort of middle-earth: in the West we are approaching new forms of multilevel governance. People are facing new forms of multiculturalism in all aspects of the society, encountering also a reform of the secular power, a crisis of the structure that was born during the Westphalia's peace and a very unstable situation concerning the international relations in the Muslim world. After the Arab spring revolution in 2010 we are witnessing a new awakening of Islamic thoughts in public affairs, not only in the revolutionary movement in Northern Africa, but also in the current Islamic State of Iraq and the Levant. It could be defined as a sort of new "autumn of nations", that period raised at the end of Second World War and at the end of the Cold War in 1989 in Eastern Europe.. I disagree with this sort of categorization in as much as

\footnotetext{
${ }^{8}$ Cf. the three fundamental Islamic charts on Human Rights in the Islamic World: the Universal Islamic declaration of Human Rights adopted by the Islamic European Council (1981), The Cairo Declaration on Human Rights in Islam (1990), the Arab Charter on Human Rights (2004). Concerning the private sector I highlights the importance of all the private institutions as Human Rights Watch/Africa or the Advisory Council of the Arab program for Human Rights \& Development which have declared several documents referring on the Universal Declaration of Human Rights
} 
the trouble concerning more some internal aspects of the Muslim World sorted by external causes (Economic crises, unemployment, political corruption, inflation) but it reflects a vulnerable structure and a kind of rift between religion and secular power. Going beyond this cross system of new powers we can observe a "wind of change" in the Islamic area but probably many different governments are refusing this possibility for a reform.

\section{Liberalism in the Muslim world}

Regardless of the importance to create a stable and peaceful community between different societies all over the world, Islamic people need to increase awareness about their own role in a globalized world in which it is up to each citizen to be involved and responsible. Islamic countries ought to open a constructive dialogue with "the other" (in Arabic we can translate it as Dar al-harb, the house of war), and with itself: a serious, deep and sustainable dialogue. A way for developing this work is the philosophic way of thinking of Muslim Liberalism: this conception aims to rise points of contact with the western tradition, although it maintains some peculiarity which makes it deeply different. It seems to be an oxymoron in terms: the term liberalism in fact comes from the eighteen-century revolution in America and Europe. However, also the term "liberalism" has different meanings. Liberal movements within Islam are pooled from a solid line-up in favour of Human Rights. This political thought is born from several varieties of philosophical currents starting from European liberalism reaching also Socialism and Marxism. Nevertheless the contemporary Muslim Liberalism nowadays continues to be ostracized by western mass-media which is affected by lack of objectivity towards oriental thoughts, and internally by conservatories who categorizes all of this as a sort of capitalism, individualism and above all as a new colonialism.

Liberal movements within Islam arose during the XVIII century with the diffusion of some revivalist currents (which changed the relationship between believers and God assuming a more public background). Shah Wali-Allah (India, 1703-1762) for instance sustained that Islamic law could not be unique and immutable but it necessarily needed to adapt to the people of a certain society and not only to the human reasoning ${ }^{9}$. Shari'a's norms have a deep connection with the Muslim society and for this reason they should evolve together; on the contrary, at that time this was rather the product of human reasoning which comes from the scholars and where the citizens were supposed to train the taqlid (imitation) and follow the teaching of the experts. This attitude represented the mainstream until XIX century until expressing the end of taqlid and the rise of jitihad, which finally becomes a right for all Muslim believers in all its aspects not

\footnotetext{
${ }^{9}$ Cf. Kurzman (1998), Liberal Islam and Its Islamic context, in C Kurzman, Liberal Islam: a Sourcebook (p. 7)
} 
expressively regulated by Quran and Sunni. The purpose was not the laicisation of the society but rather the exigency of a refurbishment. Some of these authors became the root of the "Islamic Reformism", a political movement, which promoted the end of taqlid even if it remained far off the modern liberalism. Moreover it gave rise to the social movement of the Brotherhood Muslim which developed in 1928 and which also became one of the most famous transnational Islamic organisations. The Liberalistic approach tries to legitimate the rights of the western declaration using tools of the Islamic tradition without using a pragmatic top-down approach.

"The feasibility of the project is based on the possibility of finding a cultural legitimacy" In fact it is fundamental for the acceptance of all the rights concerning the social rights until reaching the rights of freedom. Thanks to it, we can expect a greater respect of the norms. Cultural legitimacy is the necessary condition of the universality of Human Rights. However we should watch out to consider it as "neutral": in fact even if we are in a liberal society it is uncertain. My point of view prefers to focus attention on practical tools. The abstraction proposed by Rawls's overlapping consensus remains too unbind with facts. Habermas in The inclusion of the other (1998) criticized Rawls's theory as a sort of Deus ex machina because there is a lack of a deliberative process which would be able to put in contact citizens. Reconsidering the dawning of philosophy: "man is a social animal" and he cannot live without this. Taking into consideration this cultural level we figure out a thesis who lays the foundations to establish solid basis for comprehension. I agree with An-Naim when he defines the cross-cultural approach but I prefer to retain only the human integrity as a sort of common denominator for a common identity, already articulated by different international declarations, particularly the 1948 Declaration. He considers human dignity as well a linchpin but I prefer to put it aside seeing it as more difficult find a common valour for defying it. Every person has got a core of personal integrity, formed precociously, which may influence one's own behaviour. It is not dominated by education or context. The persons are not influenced by society and by its conduct deemed as a sort of common praxis. Moral integrity is based on the consideration of the importance of responsibility: choosing and taking the responsibility of developing one's own culture. My considerations seem to be originated by the nature of law, in spite of this I address my target on the Principle of Reciprocity. This is considered a common basis for dialogue between cultures since it can be discovered in many of them, both in the present and in the past. Carefully, we do not interpret it in a utilitarian meaning, as a sort of do ut des. Furthermore reciprocity cannot be a justification for the perpetration of a wrongful act. 
The last point to discuss for a complete discourse about Human Rights in Islam concerns the concept of public reason. In the Islamic countries especially in the Middle East area there seems to be a lack of dialogic approach between people. Public reason is often translated as reason of the sovereign where the political elites maintain a detached approach, making the interest of their own social class. Therefore we can understand the difficulty to reach a common public reason for all the social classes if this work remains at an international level in the hands of a government without a constructive accountability in emphasizing the role of civil society. Actions ought to coalesce through a combination of different efforts where the key role is bound by local NGOs, with the help of international cooperation and pressure. In fact, the growing of globalization and other distinct factors are transforming the social context of these territories. This situation brings to seeking the best tools for determining long terms strategies and immediate responses. An-Naim wants to consider an indispensable step forward the breaking of what he has called "Human Rights dependency"10 by which he means "the widely prevalent perception that the governments of developing countries are more responsive to international pressure for the protection of Human Rights in their countries, than to the activities of local NGOs and other actors within their own societies ${ }^{11}$ ". Due to the political situation, the indispensable importance of these local entities remains extremely problematic. Moreover the international NGOs are not accountable for the local society which considers they have a sort of western charity agenda.

Liberal movements prefer to imagine the "rethinking of Islam" using traditional tools, just to get it more sustainable and to avoid a cultural trauma. Eminent thinkers proposed different solutions and in my assessment I refer to one of the methods proposed by Charfi: the hermeneutic $\operatorname{approach}^{12}$. His thought focuses on the religious point of view, which I assume is the common basis of society in the Islamic world whereby laws and praxis. These considerations touches the spirit of the Quran very well and of the tradition posing them within the global divine project. This approach supposes the role of the time to understand if some rules will became inadequate or not. The Quran has already used this policy for waiving some verses on the basis of lex posterior derogat priori.

Focusing on the wide landscape of Shari' a reinterpretation is really complex but possible nevertheless: using one of the more general interpretations; it means "great route for reaching

\footnotetext{
10 An-Naim (2010), Human Rights in the Arab World: A regional perspective in Abdullahi An-Naim edited by Mashood A. Baderin, Islam and Human Rights (p. 136)

${ }^{11}$ Ibid. (p. 136).

12 M. Charfi (1998), Islam y libertad (p.158)
} 
God", in this case Shari' a would achieve a meta-juridical and universal principle, a sort of criteria of justice. Unfortunately, Shari' a assumes the connotation of positive law, bounded with tradition. This second interpretation doesn't face the world problem, denying the modernisation of Muslim society. However, considering Shari' a as a combination of principles and not as a conglomeration of positive rules, represents a positive changing without assuming a rupture with tradition. Considering the work of Tariq Ramadan in Radical Reform (2009) and withdrawing some Arabic words from Islamic Science sources ${ }^{13}$, we can find the term tajdid: rebirth, renewal, regeneration. The meaning can be attributed by one prophet hadith (narration about the life of the Prophet or what he approved): "God will send this [Muslim] community, every hundreds years, someone/some people who will renew [yujaddidu] its religion". These is famous words have a deep purport: the intention is to fix the importance of a stable guide for the Muslim community through a group of people able to lead this renewal able to "regenerate" the Islamic religion without putting principles and basic ideas into question. Our reading and understanding "will be renewed by the contribution of Scholars and thinkers who will point to new perspectives by reviving timeless faith" (Ramadan). According to the hadith reported by Abu Dawud the other term used several times in Quran and in the ahadith (pl.) for covering the concept of improving, reconciling and reforming Islam is $I s l a b^{14}$. The Midianite prophet Shu'ayb in the Quran said: "I do not desire, in opposition to you, to do that which I forbid you to do. I desire nothing but reform [purification] (al-Islab) as far as I am able". The purpose aims to reconstruct the original meaning of the object, to remake order and to reform

\section{Conclusion}

Islam liberalism may be defined as a juridical-cultural liberalism and not political as it was born in the western area. This connotation helps the construction, through the identification of a juridical liberalism and later submits a political liberalism with the acknowledgment and safeguard of Human Rights. Moreover this approach is able to identify a useful contribution for the recognition of universal rights in the daily life of Islamic ummah and not only in declaration of governments. This critical study establishes as fundamental a renovation of relationship between people and sources. However reforming does not mean changing referent and model in order to imitate the western liberalism. It is important to change outlook, human and social context and above all rebalancing legitimacy and authority. In practice, the possibilities are numerous: firstly

${ }^{13}$ Abu Hamid al-Ghazali (1970), Scritti scelti (p. 22 )

${ }^{14}$ Abu Dawud is considered one of the main collectors of prophetic hadith. In fact Sunni Muslim consider its Sunan Abi Dawnd the third of the six "canonical" hadith collections. 
being coherent with the main goals of Islam religion, and then starting to create space for study outside religious building where scholars could start exchange collaborations, ideas and sharing practices with other contexts even if with different religions and therefore learning by interacting. In this moment of worldwide cultural crisis I assume as fundamental the rise of a moral and ethical personal dignity where States can serve the ideals of social justice and peace in order to build a political life with the neutrality of religion. 


\section{Bibliography}

Al- Djazairi, Djabar Abu Bakr (2010): La via del Musulmano. Perugia: Unione degli Studenti Musulmani in Italia (U.S.M.I.).

An-Naim, Abdullahi A. (1990): Human Rights in Africa. Cross Cultural perspectives. Washington: The Brookings Institution.

An-Naim, Abdullahi A. (2010): Islam and Human Rights, edited by Mashood A. Baderin. Burlington: Ashgate Publishing Company.

An-Naim, Abdullahi A. (1996): Towards an Islamic reformation. New York: Syracuse University Press.

Anselmo, D. (2007): Sharia e Diritti Umani. Torino: Giappichelli.

Charfi, M. (1998): Islam y libertad: el malantendido Historico. Granada: Almed.

Habermas, J. (1998): L’inclusione dell'altro. Milano: Feltrinelli.

Hamid al-Ghazali, Abu (1970): Scritti scelti, edited by L. Veccia Vaglieri and R. Rubinacci. Torino: UTET.

Kurzman, C. (1998): Liberal Islam: a Sourcebook. New York: Oxford University Press.

Ramadan, T. (2009): Radical Reform - Islam Ethics and Liberation. New York: Oxford University Press.

Rawls, J. (2001): Il Diritto dei Popoli. Torino: Einaudi Edition.

Ramadan, T. (2008): Islam e Liberta, trans. C. Testi. Torino: Einaudi.

Roy, O. (2003): Global Muslim, trans. It. L. Cornalba. Milano: Feltrinelli Edition.

Talbi, M. (1999): Le vie del dialogo nell'Islam, trans. V. Abrate. Torino: Fondazione G. Agnelli. 